\title{
THE ROLE OF ANAEROBIC METABOLISM IN THE PERFORMANCE OF MILD MUSCULAR WORK. I. RELATIONSHIP TO OXYGEN CONSUMPTION AND CARDIAC OUTPUT, AND THE EFFECT OF CONGESTIVE HEART FAILURE ${ }^{1}$
}

\author{
By WILLIAM E. HUCKABEE2 \\ AND
}

WALTER E. JUDSON ${ }^{3}$

\begin{abstract}
(From the Robert Dawson Evans Memorial, Massachusetts Memorial Hospitals, and the Department of Medicine, Boston University School of Medicine, Boston, Mass.)
\end{abstract}

(Submitted for publication February 4, 1958; accepted July 17, 1958)

Anaerobic energy-yielding processes in human tissues, as estimated from $\mathrm{O}_{2}$-debt, have been thought to be important in the exertions of athletics $(1,2)$ or of hard work (3). Recent studies (4) have suggested that the anaerobic metabolism induced by hypoxia plays a part in almost all activity, whether severe or mild, although mild activity may be associated with $\mathrm{O}_{2}$-debts too small to measure. Rather than an emergency mechanism, anaerobic metabolism may therefore be a part of the ordinary daily life of mammals. This anaerobic mechanism of energy supply is called forth by inadequacy of oxygen supply relative to tissue requirements, and the ability of the oxygen transport mechanisms to meet tissue demands may become the critical factor at specific levels of relative hypoxia (5). Therefore it seemed possible that in patients with diseases of the oxygen transport system (lungs, blood and circulation) tissue anaerobic metabolism might be even more important, and perhaps a significant determinant of physical disability.

The older concept of $\mathrm{O}_{2}$-debt (6) is a static one largely because of the manner of its measurement, but it has contributed a great deal to the understanding of oxygen supply which could not be learned from blood flow and oxygen concentrations alone. Debt development has been found to be the same in patients with heart

1 Aided in part by a grant from the National Heart Institute, National Institutes of Health, United States Public Health Service.

2 Work done in part during tenure of Research Fellowship and Fellowship as Established Investigator of the American Heart Association.

${ }^{3}$ Present address: Indianapolis, Ind. failure as in normal persons (7-9). While this might well be regarded as one of the most important facts of the physiology of heart failure, $\mathrm{O}_{2}$-debt has certain conceptual and practical limitations which will be considered in a later section. However, a workable hypothesis concerning the source of tissue anaerobic energy in man under these circumstances, employing the concept of "excess lactate" $(10,4,5)$, permits a more mobile viewpoint which can be extended somewhat beyond the reach of the $\mathrm{O}_{2}$-debt concept; this notion might be described initially as the instantaneous rate of formation of $\mathrm{O}_{2}$-debt. On the other hand, if the original static idea is not retained in the terminology, we may conveniently call this notion "anaerobic metabolic rate." If there is a continuous interplay between aerobic and anaerobic metabolism during the daily life of human subjects, as suggested by the apparent occurrence of anaerobic metabolism during slight physical activity, then the quantitative balance between these two phenomena from time to time is of interest both as a physiologic mechanism of work and as a part of the clinical problems of fatigue, dyspnea and physical disability in circulatory disease, problems which have not been satisfactorily understood on the basis of oxygen and blood flow measurements.

The present investigations in normal subjects and in patients with heart disease were undertaken for the purpose of examining the general significance of blood oxygen concentrations, in relation to metabolic adequacy of oxygen supply, by comparing anaerobic and aerobic metabolic rates occurring during mild exercise comparable to the everyday activity of patients. 


\section{METHODS}

The normal subjects were either hospital patients recovering from minor infectious diseases or patients seeking cardiac or other diagnostic investigation but having no symptoms or other abnormality revealed by the usual diagnostic methods or, in appropriate instances, by cardiac catheterization. The patients in heart failure all had clear-cut disability, i.e., exertional dyspnea, orthopnea, edema, excessive fatigue, although some had only slight complaints. Those with very mild congestive failure (Class II) were included only if these complaints were consistent at various times and could be definitely ascertained to be progressively increasing. All had abnormal hearts on fluoroscopy. Thirteen of the patients exhibited clinical signs of salt retention in the form of edema at the time of the study, but 11 did not. Dyspnea was present in all, however. Six patients had essential hypertension, five had mitral stenosis, two had predominant mitral

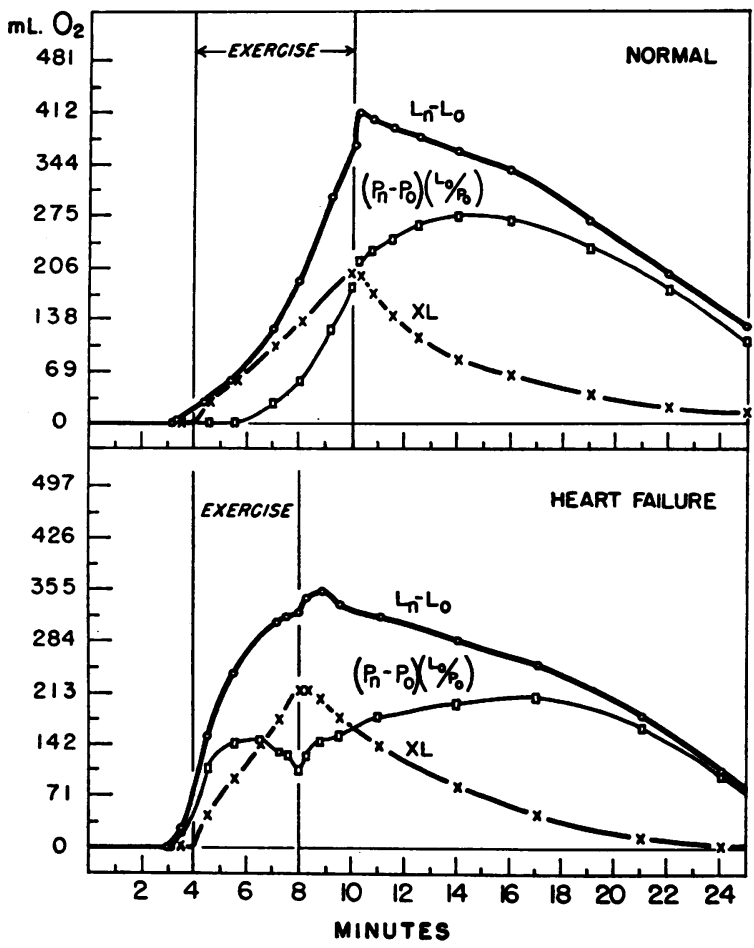

Fig. 1. Typical Exercise Experiments in (A) a Normal Man and (B) a Patient with Congestive Heart failure (Hypertensive, Class III)

The pattern of changes in body lactate $\left(L_{n}-L_{0}\right)$, pyruvate $\left[\left(P_{n}-P_{0}\right)\left(L_{0} / P_{0}\right)\right]$ and excess lactate $(X L)$ with time are shown. Units are milliliters $\mathrm{O}_{2}$-debt equivalents described in the text. The difference in contours of the time curves of pyruvate change in normal and heart failure subjects illustrates the variations which occur commonly, but either curve (as well as other variations) may be regarded as equally common in both normal and heart failure subjects. regurgitation, four had aortic valvular disease and seven had "arteriosclerotic" (senile) heart disease. In the 17 patients studied by cardiac catheterization, pulmonary arterial systolic pressures exceeded $32 \mathrm{~mm}$. $\mathrm{Hg}$ and wedge pressures exceeded $18 \mathrm{~mm}$. in every case. Eleven patients (including seven of the nine who had edema) exhibited a right atrial pressure of $10 \mathrm{~mm}$. $\mathrm{Hg}$ or above.

The subjects came to the laboratory fasting. A needle was placed in the brachial artery and in some instances a cardiac catheter was passed into the pulmonary artery, after which the subjects were allowed to rest comfortably for an hour or more. In seven of the normal subjects and five of the patients the metabolic rate at the end of this control period was compared with the basal metabolic rate, as determined on a previous occasion when no other procedure was being carried out, and in no instance was found to differ by more than 5 per cent. Collections of arterial blood were made as previously described (11) with instantaneous denaturation of the blood and with simultaneous determinations of blood water content. Analyses for pyruvate and lactate concentrations were performed as described and expressed as millimoles per liter of blood water. 4-Aminoantipyrine (12) was used to determine total body water content. Determinations of oxygen in arterial blood $\left(\mathrm{CaO}_{2}\right)$ and in mixed venous blood $\left(\mathrm{C}_{\mathrm{O}_{2}}\right)$ were carried out either manometrically or in some instances spectrophotometrically (13) and rates of oxygen consumption $\left(\dot{\mathrm{V}}_{\mathrm{O}_{2}}\right)$ were determined from Haldane analysis of expired air for oxygen, carbon dioxide and nitrogen, and from the volume of air inspired from a calibrated spirometer. The expired air and blood samples were collected simultaneously and continuously over periods of one and one-half to two minutes and cardiac output calculated by the Fick principle. In some instances cardiac output was determined by the dye dilution technique (14) or by both methods. Exercise consisted of a walking motion of the legs at a constant rate while the subject lay supine. Oxygen consumption and cardiac output for the exercise period were determined after five minutes or more of steady activity. This exercise was found to produce a decrease in urinary sodium excretion in patients with congestive heart failure but did not do so in normal man even when continued for 30 minutes.

Concentrations of "excess lactate" (XL) were calculated as described previously (10) from pyruvate and lactate changes, according to the following equation:

$$
\mathrm{XL}=\left(\mathrm{L}_{\mathrm{n}}-\mathrm{L}_{0}\right)-\left(\mathrm{P}_{\mathrm{n}}-\mathrm{P}_{0}\right)\left(\mathrm{L}_{0} / \mathrm{P}_{0}\right),
$$

where $L_{0}$ and $L_{n}$ and $P_{0}$ and $P_{n}$ are lactate and pyruvate concentrations in arterial blood water at any two times, $t_{0}$ and $t_{n}$. In the present experiments $t_{n}$ was taken as any time during the steady state of exercise and $t_{0}$ was taken during the near-basal state of the control period. This calculated fraction of any total lactate change (XL) is attributable to the changes in [DPNH]/[DPN] (diphosphopyridine nucleotide) of tissues rather than in changes in pyruvate, and therefore gives an estimate of the energy derived anaerobically from the lactic dehydrogenase system in response to inadequacy of intracellular oxygen supply relative to cellular energy requirements (10) during 
the time interval studied. This energy may be expressed in any of a variety of units, but for the purpose of comparison with rates of oxygen consumption the dimensions used are oxygen-equivalents in milliliters, derived from XL by multiplying by the factor $11.2 \mathrm{ml}$. of oxygen per $\mathrm{mM}$ of $\mathrm{XL}$ (4). The total body $\mathrm{XL}$ is in turn derived from concentration by multiplying by the volume of body water (4).

\section{RESULTS}

Figure 1 shows typical results obtained during mild exercise in a normal subject and in a patient disabled by congestive heart failure (Class III). The observed change in body lactate expressed in oxygen-equivalents (derived from blood lactate concentrations as described above for $\mathrm{XL}$ ) is shown by the curves marked $L_{n}-L_{0}$. No important difference is noticeable between the curves for normal and clinically abnormal subjects; this was a common finding. Two typical forms of the curves are shown, but both types were equally frequent in the two groups of subjects, normal and heart failure. The change in lactate which would be expected from the observed change in pyruvate is shown by the curves marked $\left(\mathrm{P}_{\mathrm{n}}-\mathrm{P}_{0}\right)\left(\mathrm{L}_{0} / \mathrm{P}_{0}\right)$. This much lactate accumulation must be attributed to alterations in pulmonary ventilation, epinephrine secretion, changes in glucose metabolism or other causes (10), but not to deficiency of oxygen supply. The algebraic differences between these two func- tions at various times is shown by the curve marked XL and represents the excess of lactate accumulation over that which can be accounted for by nonhypoxic causes. The patient illustrated by Figure 1A showed a total XL accumulation of about the same as that of the typical normal subject. The grouped data from 14 normal subjects and from 24 patients with clinical congestive heart failure (disability varying from Class II to Class IV) are shown in the scatter diagrams of Figure 3.

\section{Cardiac output and arteriovenous oxygen difference}

Exercise in the normal subjects lasted 8 to 14 minutes, averaging 11 minutes, while that in heart failure patients lasted 5 to 10 minutes, averaging 7.6 minutes. The values for cardiac output, oxygen consumption and arteriovenous oxygen difference at rest, and the changes accompanying exercise, are summarized in Table I for both normal subjects and patients with congestive heart failure. The individual changes of cardiac output (Q்) and arteriovenous oxygen difference $\left(\mathrm{CaO}_{2}-\mathrm{C}_{\mathrm{V}_{2}}\right)$ are depicted in Figure 2.

The two groups of subjects differed "significantly" ( $p<0.01$ ) from each other in both cardiac output and arteriovenous oxygen difference at rest, but the mean increases in cardiac output during exercise did not differ significantly. The

TABLE I

Mean values for measured and derived variables in 14 normal subjects and in 24 patients with heart failure at rest and the changes which occurred on exercise*

\begin{tabular}{|c|c|c|c|c|c|c|}
\hline \multirow{3}{*}{$\begin{array}{c}\begin{array}{c}\text { Measured and } \\
\text { derived variables }\end{array} \\
\text { me (min.) }\end{array}$} & \multicolumn{2}{|r|}{ Normal } & \multicolumn{4}{|c|}{ Heart failure } \\
\hline & Rest & Change with exercise & \multicolumn{2}{|l|}{ Rest } & \multicolumn{2}{|c|}{ Change with exercise } \\
\hline & & $11 \mathrm{~min}$. (8 to 14 ) & & $t$ & $7.6 \mathrm{~min} .(5$ to 10$)$ & $t$ \\
\hline $\begin{array}{l}\mathrm{Qa} / \mathrm{M} .{ }^{2}\left(L . / \min . / M .^{2}\right) \\
\mathrm{CaO}_{2}-\mathrm{C}_{\mathrm{O}_{2}}\left(\operatorname{ml} . / L{ }^{2}\right) \\
\Delta \mathrm{O}_{\mathrm{a}} / \Delta\left(\mathrm{Ca}_{0_{2}}-\mathrm{C}_{\mathrm{O}_{2}}\right)\end{array}$ & $\begin{array}{l}3.19 \pm 0.29 \\
44.1 \pm 5.1\end{array}$ & $\begin{array}{l}4.04 \pm 2.22 \\
29.8 \pm 8.2\end{array}$ & $\begin{array}{l}2.50 \pm 0.59 \\
56.4 \pm 17.0\end{array}$ & $\begin{array}{l}<0.01 \\
<0.01\end{array}$ & $\begin{array}{l}3.08 \pm 1.60 \\
39.0 \pm 14.0\end{array}$ & $\begin{array}{l}0.05 \\
0.01\end{array}$ \\
\hline $\begin{array}{l}(L . / \text { min. }) \\
\mathrm{Paco}_{2}(\mathrm{~mm} . \mathrm{Hg})\end{array}$ & $38 \pm 2$ & $\begin{array}{c}6.7 \pm 4.1(4.2-13.3) \\
+2 \pm 4\end{array}$ & $37 \pm 2$ & & $\begin{aligned} 5.1 & \pm 4.3(0.5-8.6) \\
& -5 \pm 4\end{aligned}$ & $\begin{array}{r}0.25 \\
<0.01\end{array}$ \\
\hline 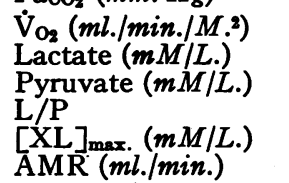 & $\begin{array}{c}165.0 \pm 45.0 \\
0.620 \pm 0.079 \\
0.148 \pm 0.053 \\
4.24 \pm 0.44\end{array}$ & $\begin{array}{c}280.0 \pm 58.6 \\
1.31 \pm 0.060 \\
0.090 \pm 0.032 \\
4.23 \pm 2.51 \\
0.830 \pm 0.420 \\
26.8 \pm 9.96(4.9-86.0)\end{array}$ & $\begin{array}{c}167.8 \pm 53.4 \\
1.024 \pm 0.149 \\
0.174 \pm 0.098 \\
4.30 \pm 0.57\end{array}$ & $\begin{array}{c}<0.01 \\
0.3\end{array}$ & $\begin{array}{c}220.9 \pm 91.8 \\
2.58 \pm 1.06 \\
0.142 \pm 0.144 \\
6.52 \pm 4.2 \\
2.370 \pm 0.750 \\
129.4 \pm 65.3\end{array}$ & $\begin{array}{r}0.02 \\
<0.01 \\
0.07 \\
0.05 \\
<0.01 \\
<0.01\end{array}$ \\
\hline$\%$ resp. $\dot{\mathrm{V}}_{\mathrm{O}_{2}}$ & & $95.1 \pm 1.73(90-98)$ & & & $71.2 \pm 8.92(50-80)$ & $<0.01$ \\
\hline $\begin{array}{l}\% \text { resp. Qa } \\
\% \text { resp. }(a-\nabla)_{o_{2}}\end{array}$ & & $\begin{array}{l}93.2 \pm 1.69 \\
92.4 \pm 1.71\end{array}$ & & & $\begin{array}{c}44.7 \pm 17.7(0-69) \\
65.8 \pm 11.4\end{array}$ & $\begin{array}{l}<0.01 \\
<0.01\end{array}$ \\
\hline
\end{tabular}

* Notations have the form: Mean \pm standard deviation (range). values.

I Indicates the probability of the values in these columns being statistically the same as the corresponding normal 


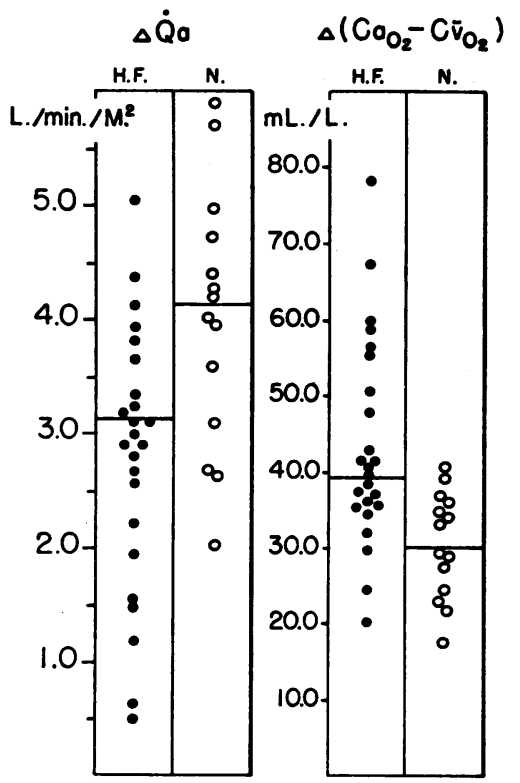

Fig. 2. Diagrams Showing the Changes in Cardiac Output $(\Delta \dot{Q} a)$ and in Arteriovenous Oxygen Difference $\Delta\left(\mathrm{Ca}_{2}-\mathrm{CV}_{\mathrm{O}_{2}}\right)$ Observed During Exercise in Normal Subjects (N.) and in Patients with Clinical Congestive Heart Failure (H.F.)

mean changes in cardiac output per liter change in oxygen consumption are also given, but did not differ significantly. Rise of $\left(\mathrm{CaO}_{2}-\mathrm{C}_{\mathrm{V}_{2}}\right)$ with exercise was higher for the heart failure patients statistically, but many values were within the normal range as shown in Figure 2.

\section{Blood lactate and pyruvate}

Blood lactate in the normal subjects increased by a mean of approximately 300 per cent above control. The values in rest and exercise are summarized in Table I. Blood lactate in the heart failure patients increased by about 400 per cent. The mean rise of blood lactate was significantly higher for the heart failure group than for the normals, but the points were widely scattered and overlapped the normal range as shown in Figure 3. The heart failure patients tended to hyperventilate consistently during exercise, raising the oxygen content of expired air and decreasing the carbon dioxide content, whereas the normal subjects uniformly slightly underventilated their lungs relative to $\dot{\mathrm{V}}_{\mathrm{O}_{2}}$ and $\dot{\mathrm{V}}_{\mathrm{CO}_{2}}$. In view of the effect of hyperventilation in producing lactic acidemia (10), most of the differ- ence between the two groups with respect to lactate could be ascribed, in the absence of further information, to a difference in breathing pattern. The rise in arterial blood lactate usually preceded the beginning of exercise, as illustrated in Figures 1 and 6, experiments in which the changes were relatively slight. Increments of blood total lactate on exercise have been found to be particularly striking in subjects noted to be anxious or fearful. Patients in apparently normal physical health who were convinced that they had heart disease (even when they exhibited no overt anxiety) have often shown lactate increases well above the "normal" range while $\mathrm{XL}$ responses were quite normal.

The ratio of lactate to pyruvate had about the same mean value in the two groups at rest, and the slightly greater rise of $\mathrm{L} / \mathrm{P}$ ratio during exercise in the heart failure group was of questionable or no significance as shown in Table I. A tendency toward hyperlactacidemia of arm venous blood in some heart failure patients was recently found by Cotes (15); it had previously been noted in an occasional patient $(2,16)$ or not found to any significant extent $(17,18)$, but the validity of methods in the earlier studies is now somewhat questionable. Resting concentrations of lactate in arterial blood shown in Table I averaged significantly higher in the heart failure group than in normal persons. Although the difference in resting pyruvate concentrations is not significant in the sense in which the word has been used here, the difference may be real but more variable.

\section{Excess lactate and anaerobic metabolic rate}

As illustrated by the second column of Figure 3 and the data of Table I, XL accumulation gave a sharper separation of the heart failure group from normal. As seen in Figures 1 and 6, and as previously found $(4,5)$, the curves of excess lactate accumulation were approximately straight lines. The slopes of these lines are shown in the third pair of diagrams of Figure $3, \mathrm{dXL} / \mathrm{dt}$. This value when expressed in milliliters oxygenequivalents per minute is referred to as the anaerobic metabolic rate (AMR) in each subject for the particular exercise experiment. The detailed calculation of AMR is described in the appendix (A). Anaerobic metabolic rates of the two groups on exercise are shown in Table I. 
These figures show a very wide separation of the two groups with almost no overlapping, and appear to be measuring some highly distinctive feature of congestive failure relative to normal.

The fall of XL during recovery after exercise was 87 per cent complete at 30 minutes in the heart failure patients, about the same as in the normals (average, 93 per cent completion in $\mathbf{3 0}$ minutes). Both were very variable.

\section{Correction for variations in severity of effort}

AMR, like most physiologic measurements which change during exercise, is greater with severe exertion and less with mild exertion (4). A simple difference in severity of exercise, then, might be the only difference between these two groups of subjects, and the heart failure patients may actually have been performing a greater amount of "internal work" (i.e., expending more energy) to account for these results, rather than exhibiting any more direct effect of the circulatory disease. This concept of internal work was referred to by Furusawa, Hill, Long and Lupton (19) as "effort," as opposed to the mechanical work (measured externally) to which it bore no simple or predictable relationship in their studies (20), even in normal subjects, nor in any one subject at different times.

Severity of effort has sometimes been estimated from the rise in rate of oxygen consumption. There is, however, clear evidence in the present data to suggest that, in the patients with heart failure, oxygen consumption did not account for the energy expenditure of exercise, since the anaerobic metabolic rate was markedly increased.

The estimate needed for this correction is the "total metabolic rate" for each exercise, or the energy cost of the effort. Total metabolic rate (TMR) was therefore calculated for each experiment as the sum of the aerobic metabolic rate of exercise $\left(\Delta \dot{\mathrm{V}}_{\mathrm{O}_{2}}\right)$ plus the anaerobic metabolic rate. The AMR in each instance could then be expressed per unit of TMR, that is, AMR/TMR. The bar graphs of Figure $4 \mathrm{~A}$ show by total height the TMR in each case; amounts of exertion were obviously very variable in both groups. In section $B$ each individual TMR is set at 100 per cent and the $\Delta \dot{V}_{O_{2}}$ and $A M R$ in each case are illustrated as fractions of the total. AMR,

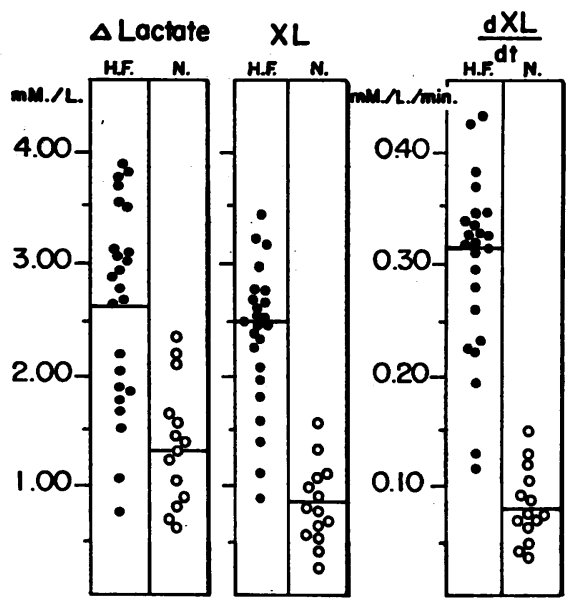

Fig. 3. Diagrams of the Data Obtained from Exercise Experiments in 14 Normal Subjects (N.) aND 24 Patients with Congestive Heart Fallure (H.F.)

The maximum change in blood lactate and excess lactate are shown in the first and second columns, respectively. Unlike $\dot{\mathrm{V}}_{\mathrm{O}_{2}}, \dot{\mathrm{Q}}_{\mathrm{a}}$ and $\left(\mathrm{Ca}_{2}-\mathrm{C} \overline{\mathrm{V}}_{\mathrm{O}_{2}}\right)$, which are constant after the first two minutes of exercise, these values change continuously and the exact timing of the measurement period is important; $d X L / d t$ is shown in the right hand column.

the upper sections, is seen to supply about 5 per cent of total energy requirement in the normal subjects and 20 to 50 per cent in the cardiac patients.

\section{Percentage response of oxygen consumption}

The same information which is provided by dividing AMR by TMR will also be given by dividing $\Delta \dot{\mathrm{V}}_{\mathrm{O}_{2}}$ by $\mathrm{TMR}$, since this is simply (1 - AMR/TMR); but the resulting value (the lower sections of the bars in Figure 4B) proves to be particularly useful. This latter figure represents the amount of response of overall oxygen delivery as a fraction of total energy requirement, i.e., oxygen consumption as a percentage of what it would have been had it supplied the total energy needs of the body. This value will be referred to as "percentage response of oxygen consumption" ( $\%$ resp. $\left.\dot{\mathrm{V}}_{\mathrm{O}_{2}}\right)$. The calculation is as follows:

$$
\% \text { resp. } \dot{\mathrm{V}}_{\mathrm{O}_{2}}=\frac{\Delta \dot{\mathrm{V}}_{\mathrm{O}_{2}} \times 100}{\mathrm{AMR}+\Delta \dot{\mathrm{V}}_{\mathrm{O}_{2}}}
$$

The anaerobic metabolic rate and change in oxygen consumption rate $\left(\Delta \dot{\mathrm{V}}_{\mathrm{O}_{2}}\right)$ are those simultaneously observed during a given change from 

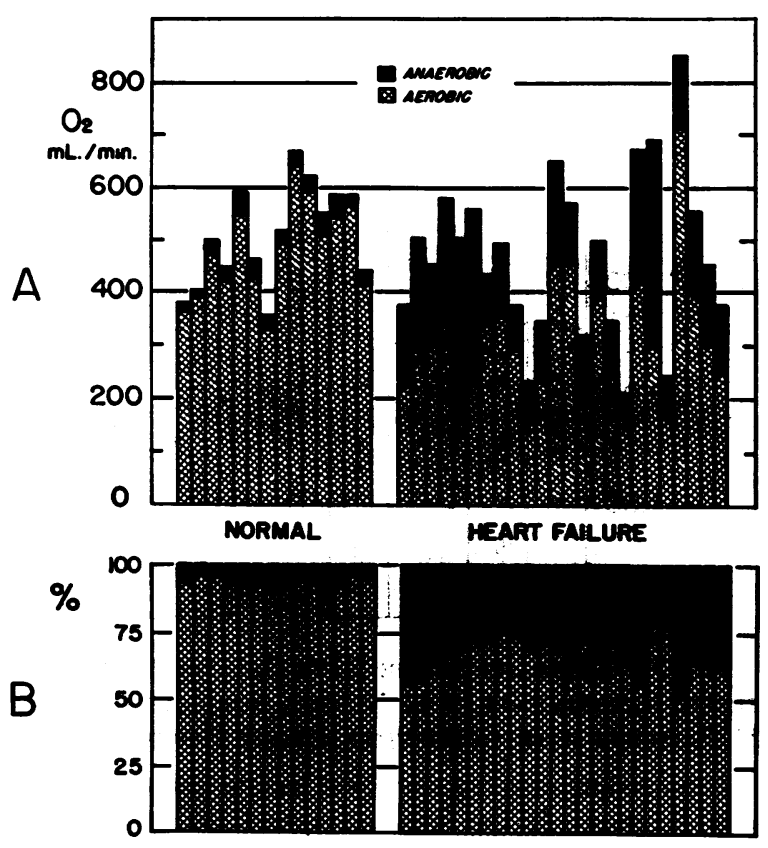

Fig. 4. Relationships of Aerobic and Anaerobic Metabolic Rates in Normal Subjects and Patients with Heart FaIlure

A. The length of the hatched bars denotes the magnitude of change in oxygen consumption for each exercise experiment and the length of each black bar denotes the magnitude of the anaerobic metabolic rate found in the same experiment. The total height of each column therefore shows the total energy requirement or total metabolic rate (TMR) of each exercise.

B. The data from section $A$ are adjusted to make each TMR equal 100 per cent. The lengths of hatched and black bars therefore denote, respectively, change in oxygen consumption and AMR as per cent of TMR for each experiment, and permit comparison of experiments of different degrees of exertion with each other.

rest to exercise. The detailed calculation is shown in the appendix (B).

This correction for differences in effort performed by each subject did not reduce the difference between the two groups of data, but on the contrary accomplished a complete separation. Normal subjects were able to supply 95.1 per cent of body oxygen requirements at the time of the need as molecular oxygen, i.e., by cardiorespiratory response. Patients with heart failure were able to supply only 50 to 80 per cent of requirement. There was no overlapping of the data, and in fact no values between 80 and 90 per cent occurred. This expression therefore appeared to measure some highly characteristic feature of heart failure.

The data for these calculations are all referred to differences between one time, $t_{n}$, and another, $t_{0}$; the former is taken to be any time during a mild exercise in these experiments, while the latter is taken as the near-basal state previously described (4). However, this experimental design is apparently not critical to the results since, as will be suggested by experiments described below, any two times in the life of the subject would probably serve equally well to reveal the percentage response of oxygen consumption, provided only that changes occurred which were measurable by the techniques employed, and that the changes were produced by exercise.

\section{Percentage response of cardiac output}

The findings which distinguish between the two groups of subjects appear to be characteristic of heart failure, the chief clinical difference between them, but failure of overall oxygen delivery could presumably be due to impairment of aspects of oxygen transport other than circulatory. Calculation of a "percentage response of cardiac output" therefore might indicate that the response of the heart in the patient group was not actually at fault. This value was obtained by calculating the "cardiac output deficit," an amount of additional cardiac output which would have been required to supply the extra oxygen needed to prevent the observed anaerobic metabolic rate, all other factors being the same:

cardiac output deficit $=\frac{\mathrm{AMR}}{\left(\mathrm{CaO}_{2}-\mathrm{C}_{\mathrm{v}_{2}}\right)_{\text {exereise (ex } .)}}$.

The percentage response of cardiac output ( $\%$ resp. $\dot{Q} a)^{4}$ then, in terms of the measured quantities, is :

$$
\begin{aligned}
\% \text { resp. } \dot{\mathrm{Q} a} & =\frac{\Delta \dot{\mathrm{Q} a} \times 100}{\Delta \dot{\mathrm{Q} a}+\text { deficit }} \\
& =\frac{\Delta \dot{\mathrm{Q} a} \times 100}{\Delta \dot{\mathrm{Q} a}+\frac{\mathrm{AMR}}{\left(\mathrm{Ca}_{\mathrm{o}_{2}}-\mathrm{C}_{\left.\mathrm{v}_{2}\right)_{\mathrm{ex}}}\right.}} .
\end{aligned}
$$

In the same manner a "percentage response

\footnotetext{
The symbol Q்a (volume flow of arterial blood per unit time) (21) is used to denote cardiac output in the sense of rate of total peripheral blood flow through the body.
} 
of arteriovenous oxygen difference" [\% resp. $\left.(\mathrm{a}-\overline{\mathrm{v}})_{\mathrm{o}_{2}}\right]$ may be calculated:

$$
\begin{array}{r}
\% \text { resp. }(\mathrm{a}-\overline{\mathrm{v}})_{\mathrm{O}_{2}} \\
=\frac{\Delta\left(\mathrm{Ca}_{\mathrm{O}_{2}}-\mathrm{C} \overline{\mathrm{v}}_{\mathrm{O}_{2}}\right) \times 100}{\Delta\left(\mathrm{Ca}_{\mathrm{O}_{2}}-\mathrm{C}_{\mathrm{v}_{2}}\right)+\frac{A M R}{\dot{Q} \mathrm{a}_{\text {ex. }}}} .
\end{array}
$$

The detailed calculation of these percentage responses is shown in the appendix (C). Figure 5 shows the calculated values plotted in scatter diagrams for the normal subjects and for the patients. Statistical descriptions are given in Table I. Points in the first pair of columns give the same values as the lower bars of Figure 4B, the $\%$ resp. $\dot{\mathrm{V}}_{\mathrm{O}_{2}}$. The values of the three percentage responses found for a given subject at one time are joined by lines to show the individual relationships. It is clear from the figure that percentage responses of cardiac output in heart failure did not prove to be nearer to normal values than was the adequacy of gross oxygen supply rate, but were more abnormal in every case.

While the lowest value of $\%$ resp. Q்a in Figure 5 was for a patient with Class IV disability and the highest for a patient with Class II disability, a close correspondence was otherwise not noted between the figures and independent estimates of clinical severity. All classes, II, III and IV, were represented in the group of points between the extremes, as indicated by the numerals adjacent to the points in Figure 5.

\section{Reproducibility of percentage responses}

The reproducibility of the derived figures is illustrated in Figure 6. The same subject underwent two different exercise experiments of differing severity. None of the measured changes was the same in Experiment B as in Experiment A. The percentage responses, however, were almost identical in the two experiments. Three normal subjects had been studied in this way in repeated experiments which differed in severity of exertion. The percentage responses of oxygen consumption were duplicated with errors of less than 3.5 per cent as shown in Table II.

In Figure 6B are also indicated two separate times of complete sampling in a single period of continuous exercise; the times are marked $t_{n^{\prime}}$ and $t_{n}$. The percentage response values given

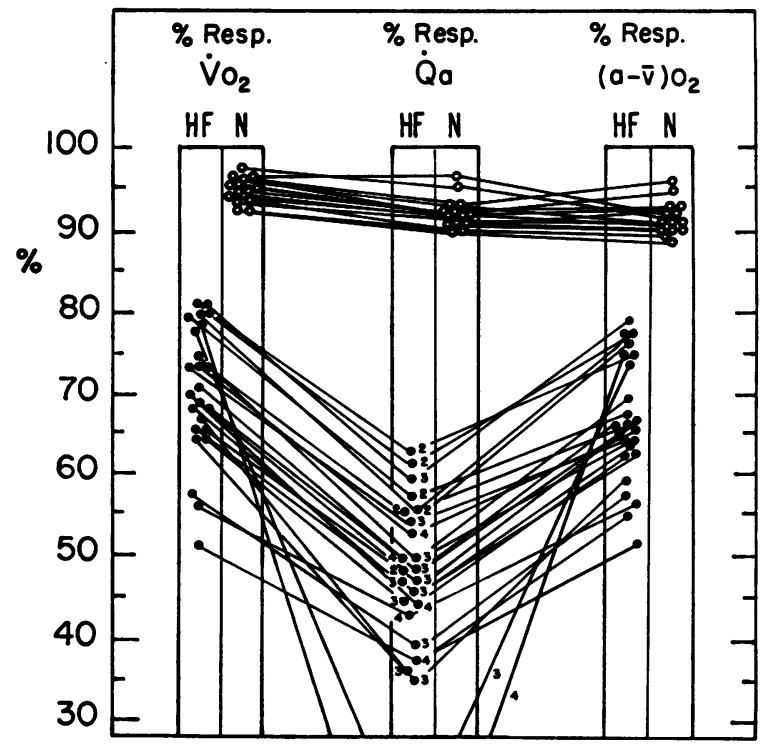

Fig. 5. Percentage Responses of Oxygen ConSumption ( $\%$ Resp. $\dot{\mathrm{O}}_{2}$ ), CARdiac OUtPut (\% REsP. Q̇a), and Arteriovenous Oxygen Difference [\% Resp. $\left.(a-\nabla)_{O_{2}}\right]$ IN Normal (N.) aNd Heart FaILURE (H.F.) SUBJECTS

Each line joins the three values obtained simultaneously in a given exercise experiment. The small numeral adjacent to each point denoting \% resp. $\dot{Q} a$ of a heart failure patient gives the clinical classification of disability assigned prior to the experiment. A division of the points by etiology yielded no systematic differences and is therefore not given here, but the three lowest points represent patients with predominant mitral regurgitation.

at the top of Figure $6 \mathrm{~B}$ and in Table II (B) are those for the entire exercise period, as they were reported for all the other experiments. However, when values obtained at time $t_{n^{\prime}}$ are compared with controls in computing percentage responses, about the same results are obtained. Of more fundamental importance, on the other hand, is the similarity of percentage responses derived from comparison of sampling times $t_{n}$ and $t_{n^{\prime}}$ for the calculation, since these are two times during exercise, without any reference to the basal state.

Table II (C) also shows the values of the percentage responses in replicate studies of four patients with congestive heart failure who originally showed various degrees of abnormality. Again the derived values were reproducible within about 3 per cent. These derived values therefore appear to represent an interrelationship which is characteristic of the individual and is 


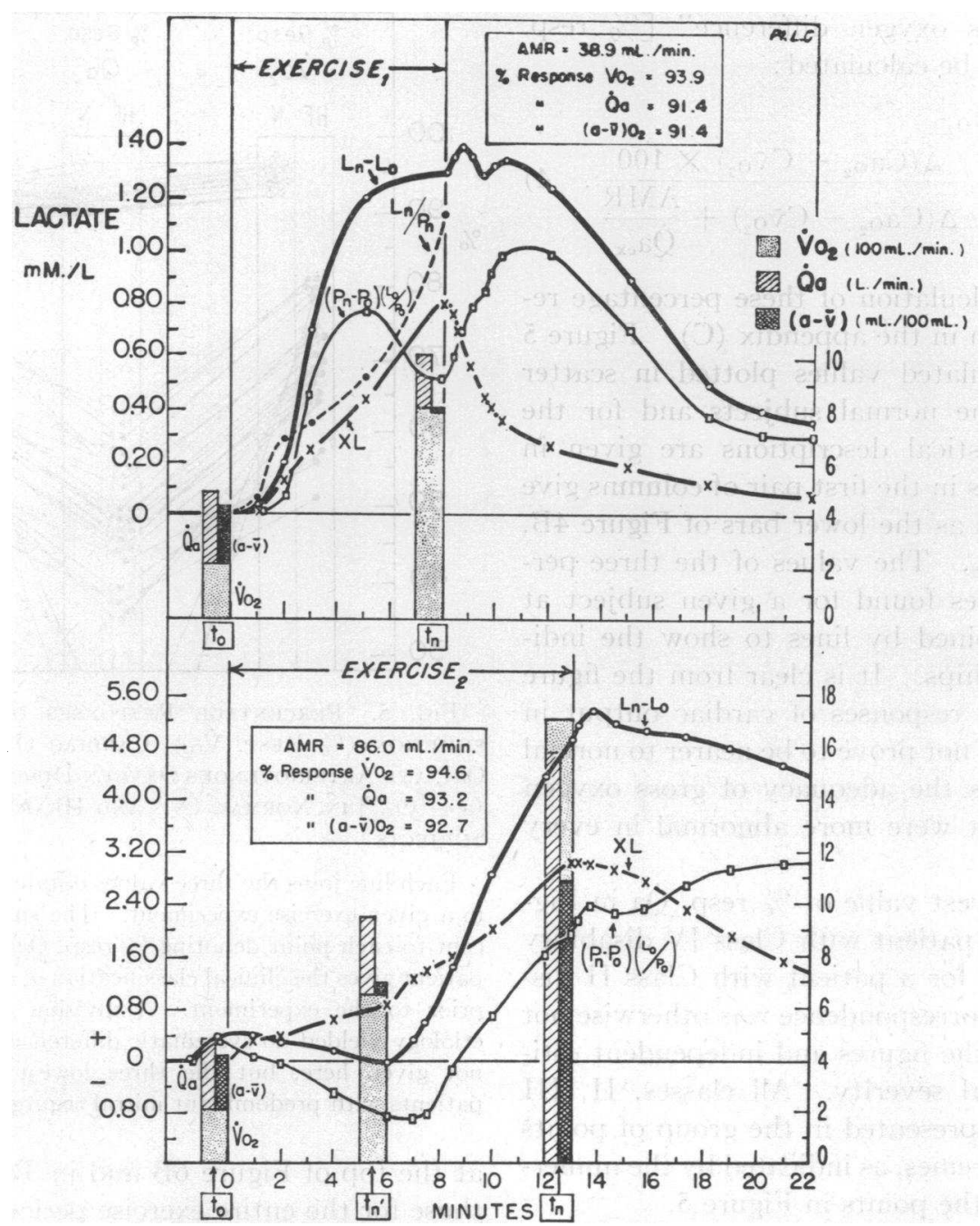

Fig. 6. Two Exercise Experiments Conducted on One Normal Subject Seven Days Apart

Experiment $B$ utilized more severe exertion and exhibited a greater rise in oxygen consumption $\left(\dot{\mathrm{V}}_{\mathrm{O}_{2}}\right)$, cardiac output ( $\dot{\mathrm{Q}}_{\mathrm{a}}$ ), arteriovenous oxygen difference $(a-\bar{v})$, blood lactate $\left(L_{n}-L_{0}\right)$, blood pyruvate $\left[\left(P_{n}-P_{0}\right)\left(L_{0} / P_{0}\right)\right]$, and excess lactate $(\mathrm{XL})$ as well as a larger anaerobic metabolic rate (AMR). Percentage responses were the same in the experiments, however. In addition to the comparison of the whole exercise periods $A$ and $B$, percentage responses can be compared in the two parts of exercise $B\left(t_{n}+t_{n^{\prime}}\right)$, and again are approximately the same.

largely independent of the severity and duration of effort (at least within the limits studied) and of the absolute values of the circulatory and respiratory responses to the effort, as well as being independent of the levels from which these responses begin.

The responses of normal persons do not approach those of heart failure patients as exercise becomes increasingly severe in the normal subject and less severe in the patient. The difference between them appears to be a difference in fundamental mechanism of energy supply.

\section{DISCUSSION}

The objective of the present experiments was to evaluate further the physiologic significance of 
TABLE II

Reproducibility of percentage responses in selected subjects

\begin{tabular}{|c|c|c|c|c|c|c|c|}
\hline Subject & $\Delta \dot{\mathrm{V}}_{\mathrm{O}_{2}}$ & $\Delta \dot{\mathbf{Q} a}$ & $\left(\mathrm{CaO}_{2}-\mathrm{Cr}_{\mathrm{O}_{2}}\right)_{\mathrm{ex}}$ & AMR & $\begin{array}{c}\% \text { resp. } \\
\dot{\mathrm{V}}_{\mathrm{O}_{2}}\end{array}$ & $\begin{array}{l}\text { \% resp. } \\
\text { Q்a }\end{array}$ & $\begin{array}{l}\text { \% resp. } \\
(a-\nabla)_{\mathrm{O}_{2}}\end{array}$ \\
\hline \multicolumn{7}{|l|}{ A. Normal } & \\
\hline $\begin{array}{l}1 \text { (a) } \\
1 \text { (b) (same day) }\end{array}$ & $\begin{array}{l}460 \\
690\end{array}$ & $\begin{array}{l}4.12 \\
4.84\end{array}$ & $\begin{array}{l}78.6 \\
93.0\end{array}$ & $\begin{array}{l}26.1 \\
36.0\end{array}$ & $\begin{array}{l}94.5 \\
95.0\end{array}$ & $\begin{array}{l}92.5 \\
92.0\end{array}$ & $\begin{array}{l}93.2 \\
93.7\end{array}$ \\
\hline $\begin{array}{l}2 \text { (a) } \\
2 \text { (b) (after } 8 \text { days) }\end{array}$ & $\begin{array}{l}665 \\
325\end{array}$ & $\begin{array}{l}6.83 \\
2.14\end{array}$ & $\begin{array}{l}76.5 \\
69.0\end{array}$ & $\begin{array}{r}33.9 \\
6.0\end{array}$ & $\begin{array}{r}95.1 \\
98.3\end{array}$ & $\begin{array}{l}93.9 \\
96.1\end{array}$ & $\begin{array}{l}95.7 \\
97.1\end{array}$ \\
\hline $\begin{array}{l}3 \text { (a) } \\
3 \text { (b) (after } 7 \text { days) }\end{array}$ & $\begin{array}{l}280 \\
897\end{array}$ & $\begin{array}{l}2.90 \\
4.66\end{array}$ & $\begin{array}{r}82.0 \\
104.2\end{array}$ & $\begin{array}{l}21.0 \\
54.0\end{array}$ & $\begin{array}{l}93.1 \\
94.3\end{array}$ & $\begin{array}{l}91.9 \\
90.0\end{array}$ & $\begin{array}{l}92.2 \\
94.2\end{array}$ \\
\hline \multicolumn{8}{|l|}{ B. Normal (Fig. 6B) } \\
\hline $\begin{array}{l}\text { Total period } \\
t_{n^{\prime}}-\text { control } \\
t_{n}-t_{n^{\prime}}\end{array}$ & $\begin{array}{r}1,510 \\
450 \\
1,060\end{array}$ & $\begin{array}{r}10.60 \\
5.00 \\
5.60\end{array}$ & $\begin{array}{r}110.0 \\
71.1 \\
110.0\end{array}$ & $\begin{array}{l}86.0 \\
26.0 \\
60.0\end{array}$ & $\begin{array}{l}94.6 \\
94.3 \\
94.7\end{array}$ & $\begin{array}{l}93.2 \\
93.4 \\
91.2\end{array}$ & $\begin{array}{l}92.7 \\
92.0 \\
90.9\end{array}$ \\
\hline \multicolumn{8}{|l|}{ C. Heart Failure } \\
\hline $\begin{array}{l}1 \text { (a) Class II, } \\
\text { A.S., A.R. } \\
1 \text { (b) (same day) }\end{array}$ & $\begin{array}{l}250 \\
375\end{array}$ & $\begin{array}{l}1.00 \\
1.46\end{array}$ & $\begin{array}{l}114.1 \\
123.2\end{array}$ & $\begin{array}{r}97.0 \\
154.2\end{array}$ & $\begin{array}{l}72.0 \\
70.9\end{array}$ & $\begin{array}{l}54.1 \\
53.9\end{array}$ & $\begin{array}{l}70.3 \\
69.2\end{array}$ \\
\hline $\begin{array}{l}2 \text { (a) Class III, } \\
\text { hypertension } \\
2 \text { (b) (same day) } \\
2 \text { (c) (after } 7 \text { days) }\end{array}$ & $\begin{array}{l}400 \\
270 \\
620\end{array}$ & $\begin{array}{l}1.24 \\
1.01 \\
1.62\end{array}$ & $\begin{array}{r}108.5 \\
94.3 \\
116.2\end{array}$ & $\begin{array}{r}129.2 \\
99.4 \\
194.7\end{array}$ & $\begin{array}{l}75.8 \\
73.2 \\
76.1\end{array}$ & $\begin{array}{l}51.0 \\
48.8 \\
49.2\end{array}$ & $\begin{array}{l}73.1 \\
71.4 \\
72.0\end{array}$ \\
\hline $\begin{array}{l}3 \text { (a) Class III, } \\
\text { A.S.H.D. } \\
3 \text { (b) (after } 7 \text { days) }\end{array}$ & $\begin{array}{l}375 \\
680\end{array}$ & $\begin{array}{l}1.81 \\
2.16\end{array}$ & $\begin{array}{r}89.7 \\
120.0\end{array}$ & $\begin{array}{l}240.0 \\
400.8\end{array}$ & $\begin{array}{l}61.0 \\
62.9\end{array}$ & $\begin{array}{l}40.3 \\
39.4\end{array}$ & $\begin{array}{l}59.0 \\
60.4\end{array}$ \\
\hline $\begin{array}{l}4 \text { (a) Class II, } \\
\text { hypertension } \\
4 \text { (b) (same day) }\end{array}$ & $\begin{array}{l}410 \\
190\end{array}$ & $\begin{array}{l}1.26 \\
0.70\end{array}$ & $\begin{array}{l}86.0 \\
78.9\end{array}$ & $\begin{array}{r}171.3 \\
90.2\end{array}$ & $\begin{array}{l}70.6 \\
67.8\end{array}$ & $\begin{array}{l}38.9 \\
38.0\end{array}$ & $\begin{array}{l}66.7 \\
64.7\end{array}$ \\
\hline
\end{tabular}

blood oxygen concentrations and of oxygen exchanges. The phenomena of exercise and of heart failure both present peculiarly complex problems with regard to the interpretation of such measurements. The metabolic evaluation undertaken consisted of two parts : the measurement of rates of anaerobic metabolism during mild exercise in normal subjects and in patients with heart failure, and the examination of the relationships between anaerobic metabolic rate and aerobic metabolic rate or oxygen consumption (with its component parts, cardiac output and arteriovenous oxygen difference). While the simplest expression of relationship would perhaps be the ratio of oxygen consumption to AMR, a value which, like the "percentage response of oxygen consumption," would be self-corrected for body size and for severity of exertion, nevertheless this is an arbitrary index. Although empirical significance could be assigned to such values with experience, this procedure would not actually represent a gain in simplicity. The "percentage response of cardiac output" is somewhat more complex in calculation, but it is analogous in concept to the percentage response of oxygen consumption. These expressions of interrelationship should not be interpreted as implying interdependence of their elements, at least not directly.

\section{A. Normal subjects}

In normal human subjects during ordinary daily life the balance between the AMR and $\dot{\mathrm{V}}_{\mathrm{O}_{2}}$ of tissues appears to be variable, but is such that $95 \pm 1.7$ per cent of the energy needs of the body are supplied at the time of the need by circulatory-respiratory response. Thus a very high percentage of the energy needs is met by the oxygen transport mechanism, but the normal response is not perfect. The role played by these 
small rates of anaerobic metabolism in slight muscular activity remains to be elucidated. Hill, Long and Lupton (1) have discussed the possibility that the $\mathrm{O}_{2}$-debt ${ }^{5}$ development of severe exercise permits a degree of exertion to which oxygen supply from outside the cell probably could not adjust instantaneously. Millikan's demonstration that intracellular $\mathrm{P}_{\mathrm{O}_{2}}$ falls markedly with each muscle contraction offers support to this idea (22). The same principle can perhaps also be applied to nonemergency activity like that of the present experiments.

The form of the time curves of excess lactate in both groups of subjects appears to be approximately a straight line, i.e., during the exercise periods of these studies, $\mathrm{dXL} / \mathrm{dt}$ was roughly constant, suggesting that anaerobic metabolic rate not only was independent of lactate and pyruvate concentrations, which changed irregularly, but also was a zero order process and independent of XL concentration itself. The lactate-pyruvate ratio altered continuously and often irregularly during exercise, as illustrated in Figure 6A, while AMR remained constant. L/P ratio, however, is presumably affected by hydrogen ion concentration, temperature and ionic strength of the cellular medium as well as by other influences.

\section{B. Effects of circulatory disease}

Whatever may be the function of small rates of anaerobic metabolism in tissues, or the method of their control in the normal organism, heart failure brings the anaerobic metabolism of patients into much greater prominence. It seems possible that some patients are dependent on this physiologic mechanism for the slightest activity. This new balance between aerobic and anaerobic metabolism was a unique difference from normal subjects in the present groups.

In view of this finding with respect to $A M R$, it may seem surprising that data available in the literature on $\mathrm{O}_{2}$-debt estimations in heart failure, when examined statistically, fail to demonstrate alteration of the normal relationship between $\mathrm{O}_{2}$-debt development and severity of exertion $(7-9,23)$. Herbst (9), for example, found a dif-

- Theoretically, $\mathrm{O}_{2}$-debt $=\int_{\mathrm{t}_{0}} \mathrm{t}_{\mathrm{m}}$ (AMR)dt, and in practice the approximation is good when conditions are ideal for the respiratory measurements (4). ference between the $\mathrm{O}_{2}$-debt development of young athletes doing maximal running exercise and that of various groups of patients who performed a moderate arm exercise; but patients with heart failure were not found to differ from those who had no heart failure, nor did they differ from a group of nervous individuals. It was shown that cardiac decompensation could not account for any metabolic differences among individuals in data published up to that time. These findings are in agreement with observations on $\mathrm{O}_{2}$-debt made in connection with the present experiments. Several writers have expressed disagreement with this idea $(18,24,25)$ but unfortunately have given no data. It might be hoped that Nylin's "cardio-pulmonary function test" (26) would show some correlation with debt; however, analysis of a number of $\mathrm{O}_{2}$-debt studies in this laboratory has revealed no correlation. In any event, other studies of this respiratory test (27) have failed to show a significant difference between normal subjects and patients with heart failure alone.

These various findings may seem difficult to reconcile with the present data, but the technique of measurement of $\mathrm{O}_{2}$-debt is very exacting $(1,4)$, and the results may be affected by many extraneous factors. Compromises in method introduced by some experimenters have no doubt increased the large random variance always found. Moreover, short bursts of strenuous exercise have usually been employed. Fairly severe exercise is essential for acceptable accuracy in $\mathrm{O}_{2}$-debt measurement, but such unsteady states with respect to respiration and diffusion of gases in the lungs and elsewhere are far more complex than those of the present experiments. The factors affecting the emergency role of anaerobic metabolism are less clear, and require further investigation.

1. Significance of "total" lactate. There appeared to be some tendency for absolute blood lactate concentration to increase more in about half the patients with heart failure than in the normal subjects. While blood total lactate concentrations were once believed to be related to oxygen deficiency (16) because of a hypothetical association with $\mathrm{O}_{2}$-debt, this idea is no longer quite tenable. The causes of nonhypoxic lactic acidemia in either group are probably multiple. 
Hyperventilation, one of the most potent causes (10), may be a significarit element in heart failure, since some of these patients characteristically hyperventilate during exercise $(7,9,15)$. Part of the variations in normal subjects, as well as the effects of heart failure itself, may be due to some influence of sedentary living, a factor which may significantly increase lactate response, although not XL responses, to exercise. Physical training reduces the lactate response to exercise $(28,29,4)$, but this likewise is often due merely to decrease of pyruvate response (4) instead of reduction of XL accumulation, and thus is frequently not due to improvement of oxygen delivery with training. However, the explanation for reduction of total lactate response by training may be its effect on ventilatory response, since physical fitness appears to cause an increased carbon dioxide retention in exercise (28).

2. Significance of blood oxygen. In severe congestive heart failure the oxygen content of mixed venous blood falls lower during exercise than the average in a group of normal subjects. This fact might have meaning if there were assurance that the internal work of doing the exercise was the same in the two groups; but, even so, the meaning in terms of tissue metabolic effects would not by any means be clear. The partial substitution of increased blood oxygen extraction for increase of blood flow is a normal mechanism of oxygen delivery and such decreases in venous blood oxygen usually occur with increased rates of delivery of oxygen, as observed in the present normal subjects, rather than being associated with decreased oxygen delivery. The intracellular $\mathrm{P}_{\mathrm{O}_{2}}$ which is critical to oxygen supply cannot be determined from gross oxygen data alone, as previously pointed out (5). There has been no evidence that the $\mathrm{C} \overline{\mathrm{v}}_{\mathrm{O}_{2}}$ in patients with heart failure represents or causes a deprivation of oxygen to the body relative to its needs. When similar blood oxygen changes occur with the breathing of low oxygen gases, for example, the rate of supply of oxygen per minute to body tissues does not diminish, and there may be no $\mathrm{O}_{2}$-debt formed (5). A more accurate point of view with respect to oxygen concentrations seems to be that some heart failure patients may deliver oxygen to the tissues in a different manner than some normal subjects.
3. Anaerobic metabolism as a third adaptive mechanism in oxygen lack. Both increased blood oxygen extraction and increased blood flow normally occur together as the need for increased oxygen delivery augments. Anaerobic tissue metabolism appears to join these changes as a third adjustment to increased oxygen need, not when the first two have become maximal, but before this. In neither the normal subjects nor the patients with heart failure was the exercise near maximal. This principle is opposed to the previous belief that "the oxygen demand or requirement of the exercise is met until the oxygen intake is at a maximum" (18). Studies of severe or "maximal" exercise $(7,9,18)$ have been of great interest in some respects, but the results in cardiac patients are those which would have been expected if the patients had been normal subjects who chose to exercise less than the others, but who were otherwise similar.

The concept of a "100 per cent response" as employed here, i.e., what the oxygen supply or cardiac output "should" be, is a theoretical value; it is nevertheless derived for a particular individual at a particular instant, and is not of the nature of a "normal" value obtained from other subjects for reference. Normal subjects do not achieve 100 per cent response. This aspect of the calculation represents its fundamental difference from changes in oxygen consumption or cardiac output per se, or changes from some mean value obtained in other individuals. The 100 per cent value is dependent on the measurement of $\mathrm{dXL} / \mathrm{dt}$, or AMR, at the desired moment in the subject who is being examined. The statistically "normal" values of the mean $\dot{Q}_{a}$ and $\dot{\mathrm{V}}_{\mathrm{O}_{2}}$ responses in the present patients clearly do not preclude the finding of low percentage responses and, in addition, this kind of cardiac output deficit may be present when changes of arteriovenous oxygen difference also are entirely "normal" statistically (30). On the other hand, the percentage response of oxygen consumption may be normal in certain subjects with abnormally reduced \% resp. Q்a (30).

The reverse is not true, however. "Percentage response of cardiac output" has as its practical upper limit the value of $\%$ resp. $\dot{\mathrm{V}}_{\mathrm{O}_{2}}$. From this characteristic it follows that depression of $\%$ resp. Q $a$ would also be expected to occur in 
any other condition which depressed $\%$ resp. $\dot{\mathrm{V}}_{\mathrm{o}_{2}}$, even when the performance of the heart was normal. However, a depression of \% resp. Q்a in excess of that occurring in \% resp. $\dot{\mathrm{O}}_{\mathrm{O}_{2}}$ would not be expected. Preliminary experience has shown that severe anemia and pulmonary disease depress the \% resp. $\dot{\mathrm{V}}_{\mathrm{O}_{2}}$ in some instances to values between 80 and 90 per cent, but when this happens the \% resp. Qa is numerically the same, in distinct contrast to the effect of congestive heart failure. These findings will be presented in detail at a later time.

The physiologic significance of the relationship between rate of tissue anaerobic metabolism and rate of blood flow is clarified somewhat further by observations on the effect of relatively slight obstructions to blood flow in the absence of heart failure (30).

4. "Inadequacy" of oxygen delivery and "insuffciency" of the circulation. Theories of the basic circulatory defect of congestive heart failure as an "inadequacy" of cardiac output have been repeatedly advanced (31-33) and denied (34). Fundamental objections to such a concept have remained; these physiological difficulties have, in effect, been discussed in the preceding sections.

In the more practical sphere, certain observations in heart failure are also difficult to explain on the basis of a "forward failure" concept. Patients with pulmonary disease (35) and anemia (36) at rest have the same $\mathrm{C} \overline{\mathrm{v}}_{\mathrm{O}_{2}}$ when in heart failure as before failure occurs. $\mathrm{P} \overline{\mathrm{v}}_{\mathrm{O}_{2}}$ falls lower in many anemic patients who have compensated hearts than is ever found in ordinary patients with decompensation (37). Further reduction of blood oxygen does not appear to accentuate progression of the syndrome of heart failure as estimated from sodium retention (38). Moreover, patients with heart failure due to common cardiac diseases of ten have no lower cardiac output or higher arteriovenous oxygen difference than patients who are clinically compensated after once having been in failure (39). Aside from these aspects of blood flow and oxygen concentration, the $\mathrm{O}_{2}$-debts developed by patients with heart failure cannot be shown to differ from normal, at least with strenuous exertion. And finally, evidence has been presented that such equivocal blood lactic acid changes as have been described have no bearing on the question of adequacy of oxygen supply $(4,5,10)$. We have not been able to substantiate our previous belief that "for any given level of anxiety or work" the patient with congestive failure has an arteriovenous oxygen difference greater than normal (33). This belief has been based largely on the idea that the "level of anxiety or work" can be judged from the rate of consumption of oxygen, an error which has been pointed out in the past for severe exertion (1) and requires no further emphasis here than to present the anaerobic metabolic rates found in mild exercise in the present series of patients. The present results, nevertheless, support the "forward failure" hypothesis concerning the fundamental derangement in congestive heart failure in suggesting that the rate of supply of oxygen to the sites of its metabolism in the tissues is inadequate to meet actual metabolic requirements in patients with congestive heart failure during even mild activity, and that this inadequacy is specifically due to inadequacy of response of the heart on demand.

The question of the physiologic significance of blood oxygen content or tension extends beyond the problem of the pathogenesis of congestive heart failure. The same question also arises in considering problems of regional ischemia and of anemia, pulmonary disease and high altitude effects (5), among others. It would appear to be necessary in such situations to use the greatest caution in assigning any significance to arterial or venous blood oxygen values as indications of oxygen deficiency relative to the needs of the tissues.

\section{SUMMARY}

1. A progressive accumulation of "excess lactate" occurred in normal human subjects during the performance of muscular work so mild as to be comparable to ordinary daily activity, a finding which indicated a shift in the mean steadystate position of the total body lactic dehydrogenase system toward the reduced state.

2. The energy derived from this anaerobic metabolism in normal persons varied widely in absolute magnitude but constituted about 5 per cent of total energy utilization in the various grades of exercise studied, suggesting that oxygen transport to tissues was 95 per cent effective in 
meeting body requirements despite decreases in mixed venous blood oxygen.

3. During similar exercise, all patients with clinical heart failure exhibited rates of anaerobic metabolism greater than those observed in normal subjects, oxygen transport being only 50 to 80 per cent effective in meeting energy requirements, regardless of whether mixed venous blood oxygen was "normal" or low.

4. The fraction of total energy requirement which could be met by oxygen transport in an individual under varying degrees of stress was a characteristic of the individual (and not of the magnitude of stress) both in normal subjects and in patients with heart failure.

5. Cardiac output responses in exercise throughout the range studied bore a predictable relationship to rates of anaerobic metabolism in normal subjects such that a further increase in cardiac output of about 7 per cent would have supplied the oxygen need which was manifested as anaerobic metabolism.

6. Exercise responses of cardiac output in the patients with heart failure were not significantly different from normal, but the relationship to arteriovenous oxygen difference and anaerobic metabolism was such that an increase of 40 to 90 per cent would have been required to supply the additional oxygen requirement of the body. This fraction invariably exceeded the fractional deficit of overall oxygen delivery, and thus exhibited a relationship which appeared to be a unique characteristic of heart failure.

7. It is concluded that: a) Rates of oxygen consumption do not accurately measure the degree of exertion in human subjects performing work, and the error is systematically greater in patients with circulatory diseases than in normal subjects. b) Estimates of molecular oxygen concentrations in body fluids, or their rates of exchange do not serve to indicate whether oxygen supply is adequate to meet the tissue requirements of the moment. c) A basic physiologic derangement in all patients with congestive heart failure is an inadequacy of oxygen supply rates to meet tissue energy requirements, an inadequacy which is specifically due to insufficiency of cardiac response, but which is neither indicated nor measured by the observed changes in oxygen delivery or cardiac output.

\section{APPENDIX}

A. Table III shows the observed data in one normal, a 32 year old woman, and one abnormal subject, a 54 year old man with hypertension and Class III congestive heart failure. From Line 2, the changes in lactate concentration with exercise $\left(L_{n}-L_{0}\right)$ were $1.252 \mathrm{mM}$ per $L$. and $3.875 \mathrm{mM}$ per $\mathrm{L}$. for the normal subject and the patient, respectively. The changes in pyruvate concentration $\left(P_{n}-P_{0}\right)$, Line 3, were $0.091 \mathrm{mM}$ per L. and $0.156 \mathrm{mM}$ per $\mathrm{L}$. The ratios of resting lactate and pyruvate concentrations $\left(\mathrm{L}_{0} / \mathrm{P}_{0}\right)$ (Lines 2 and 3 ) were 3.91 and 5.73. Substituting in Equation 1

$$
\mathrm{XL}=\left(\mathrm{L}_{\mathrm{n}}-\mathrm{L}_{0}\right)-\left(\mathrm{P}_{\mathrm{n}}-\mathrm{P}_{0}\right)\left(\mathrm{L}_{0} / \mathrm{P}_{0}\right)
$$

gives final $\mathrm{XL}$ concentrations of $0.896 \mathrm{mM}$ per $\mathrm{L}$. in the normal subject and $3.939 \mathrm{mM}$ per $\mathrm{L}$. in the patient with heart disease. XL concentration per liter of water is multiplied by the volume of water in the body, $W_{b}$, for each subject (Line 4) to give total XL accumulations of 27.0 and 116.6 millimoles. From the durations of exercise in Line 1 , the rates of accumulation are shown to be 2.70 $\mathrm{mM}$ per minute and $12.96 \mathrm{mM}$ per minute. The oxygen equivalent of each millimole of $\mathrm{XL}$ is taken to be $11.2 \mathrm{ml}$., giving AMR values of $30.2 \mathrm{ml}$. per minute and $145.0 \mathrm{ml}$. per minute, respectively. These data illustrate the occurence of high blood lactate with high AMR. However, Section $C$ gives an example of very marked differences in AMR in two subjects with normal lactate changes.

TABLE III

Observed data from experiments on one normal subject and one subject with congestive heart failure, showing calculation of excess lactate $(X L)$ and anaerobic metabolic rate $(A M R)$

\begin{tabular}{|c|c|c|c|c|}
\hline & \multicolumn{2}{|c|}{$\begin{array}{c}\text { Normal } \\
\text { (female, } 32 \text { yrs.) }\end{array}$} & \multicolumn{2}{|c|}{$\begin{array}{l}\text { Heart failure } \\
\text { (male, } 54 \text { yrs.) }\end{array}$} \\
\hline & Rest & Exercise & Rest & Exercise \\
\hline $\begin{array}{l}\text { Duration }(\min .) \\
\text { Lactate }(m M / L .) \\
\text { Pyruvate }(m M / L .) \\
\text { Weight }(K g .) \\
\mathrm{W}_{\mathrm{b}}(L .)\end{array}$ & $\begin{array}{l}0.614 \\
0.157 \\
61.6 \\
30.1\end{array}$ & $\begin{array}{l}10.0 \\
1.866 \\
0.248\end{array}$ & $\begin{array}{l}0.956 \\
0.167 \\
54.6 \\
29.6\end{array}$ & $\begin{array}{l}9.0 \\
4.831 \\
0.323\end{array}$ \\
\hline $\begin{array}{l}\mathrm{XL}(m M / L .) \\
\mathrm{AMR}(m l . / m i n .)\end{array}$ & & $\begin{array}{l}0.896 \\
30.2\end{array}$ & & $\begin{array}{l}3.939 \\
145.0\end{array}$ \\
\hline
\end{tabular}


TABLE IV

Observed data from experiments on one normal subject and one subject with congestive heart failure, showing calculation of percentage response of oxygen consumption (\% resp. $\left.\dot{V}_{\mathrm{O}_{2}}\right)$

\begin{tabular}{|c|c|c|c|c|}
\hline & \multicolumn{2}{|c|}{$\begin{array}{c}\text { Normal } \\
\text { (female, } 52 \text { yrs.) }\end{array}$} & \multicolumn{2}{|c|}{$\begin{array}{c}\text { Heart failure } \\
\text { (male, } 36 \text { yrs.)* }\end{array}$} \\
\hline & Rest & Exercise & Rest & Exercise \\
\hline $\begin{array}{l}\text { Duration (min.) } \\
\text { Lactate }(m M / L .) \\
\text { Pyruvate }(m M / L .) \\
\text { Weight }(K g .) \\
\text { Surface area }\left(M .{ }^{2}\right) \\
\mathrm{W}_{\mathrm{b}}(L .)\end{array}$ & $\begin{array}{c}0.550 \\
0.135 \\
52.0 \\
1.51 \\
24.5\end{array}$ & $\begin{array}{l}7.0 \\
1.186 \\
0.220\end{array}$ & $\begin{array}{c}0.870 \\
0.205 \\
72.0 \\
2.04 \\
39.4\end{array}$ & $\begin{array}{l}8.0 \\
3.638 \\
0.406\end{array}$ \\
\hline$\dot{\mathrm{V}}_{\mathrm{O}_{2}}(\operatorname{ml} . / \min )$. & 196.5 & 399.0 & 365.0 & 853.0 \\
\hline$\dot{\mathrm{V}}_{\mathrm{O}_{2}}\left(\operatorname{ml} . / \min . / M .{ }^{2}\right)$ & 130.0 & 264.0 & 179.0 & 418.0 \\
\hline$\dot{\mathrm{V}}(\operatorname{ml} . / \min )$. & $5,150.0$ & $1,020.0$ & $7,920.0$ & $21,300.0$ \\
\hline $\begin{array}{l}\mathrm{XL}(m M / L .) \\
\mathrm{AMR}(m l . / m i n .)\end{array}$ & & $\begin{array}{l}0.290 \\
11.4\end{array}$ & & $\begin{array}{l}2.785 \\
153.6\end{array}$ \\
\hline$\%$ resp. $\mathrm{V}_{\mathrm{O}_{2}}(\%)$ & & 94.7 & & 76.0 \\
\hline
\end{tabular}

* Protocols illustrate the occurrence of a low $\%$ resp. $\dot{\mathrm{V}}_{\mathrm{O}_{2}}$ in a patient whose increase in $\dot{\mathrm{V}}_{\mathrm{O}_{2}}$ was apparently normal.

B. Table IV gives the original data obtained from one normal subject and a patient with congestive heart failure (Class II, mitral stenosis and regurgitation, edema for one year). Substituting, as in $\mathrm{A}$, in the composite equation

$$
A M R=\frac{11.2 W_{b}\left[\left(L_{n}-L_{0}\right)-\left(P_{n}-P_{0}\right)\left(L_{0} / P_{0}\right)\right]}{t}
$$

AMR values of $11.4 \mathrm{ml}$. per minute and $153.6 \mathrm{ml}$. per minute are obtained in the two subjects. The changes in oxygen consumption for the experiments $\left(\Delta \dot{\mathrm{V}}_{\mathrm{O}_{2}}\right)$, Line 7 , were $202.5 \mathrm{ml}$. per minute for the normal subject and 488 ml. per minute for the patient. Substituting in Equation 2

$$
\% \text { resp. } \dot{\mathrm{V}}_{\mathrm{O}_{2}}=\frac{\Delta \dot{\mathrm{V}}_{\mathrm{O}_{2}}}{\mathrm{AMR}+\Delta \dot{\mathrm{V}}_{\mathrm{O}_{2}}}
$$

gives percentage responses of oxygen consumption of $\mathbf{9 5 . 0}$ per cent and 76.0 per cent for the normal subject and the

TABLE V

Observed data from experiments on one normal subject and one subject with congestive heart failure,

\begin{tabular}{|c|c|c|c|c|}
\hline & \multicolumn{2}{|c|}{$\begin{array}{c}\text { Normal } \\
\text { (female, } 39 \text { yrs.) }\end{array}$} & \multicolumn{2}{|c|}{$\begin{array}{c}\text { Heart failure } \\
\text { (female, } 64 \text { yrs.)* }\end{array}$} \\
\hline & Rest & Exercise & Rest & Exercise \\
\hline $\begin{array}{l}\text { Duration }(m i n .) \\
\text { Lactate }(m M / L)) \\
\text { Pyruvate }(m M / L .) \\
W_{\mathrm{b}}(L .) \\
\text { Surface area }\left(M .^{2}\right)\end{array}$ & $\begin{array}{l}0.760 \\
0.159 \\
24.3 \\
1.44\end{array}$ & $\begin{array}{l}5.0 \\
2.822 \\
0.311\end{array}$ & $\begin{array}{c}0.714 \\
0.138 \\
38.0 \\
1.90\end{array}$ & $\begin{array}{l}5.0 \\
3.163 \\
0.210\end{array}$ \\
\hline$\dot{\mathrm{V}}_{\mathrm{O}_{2}}(\operatorname{ml} . / \min )$. & 198.0 & 836.0 & 351.0 & $1,208.0$ \\
\hline$\dot{\mathrm{V}}(m l . / m i n)$. & $5,350.0$ & $22,000.0$ & $8,450.0$ & $14,050.0$ \\
\hline $\begin{array}{l}\mathrm{Q} \mathrm{Q}(L . / m i n .) \\
\mathrm{Ca}_{2}-\mathrm{C}_{\mathrm{O}_{2}}(m l . / L .) \\
\mathrm{RA}(m m . H g) \\
\mathrm{PA}(m m . H g) \\
\mathrm{PC}(m m . H g)\end{array}$ & $\begin{array}{c}4.83 \\
41.0 \\
4.0 \\
16 / 7 \\
5\end{array}$ & $\begin{array}{l}10.60 \\
78.9 \\
17 / 7\end{array}$ & $\begin{array}{l}8.07 \\
43.5 \\
11.0 \\
34 / 19 \\
8\end{array}$ & $\begin{array}{l}11.50 \\
105.0 \\
70 / 42 \\
25\end{array}$ \\
\hline $\begin{array}{l}\mathrm{XL}(m M / L .) \\
\mathrm{dXL} / \mathrm{dt}(m M / L . / m i n .) \\
\mathrm{AMR}(m l . / m i n .)\end{array}$ & & $\begin{array}{l}0.643 \\
0.129 \\
35.0\end{array}$ & & $\begin{array}{l}2.790 \\
0.558 \\
237.5\end{array}$ \\
\hline$\%$ resp. $\dot{\mathrm{V}}_{\mathrm{O}_{2}}(\%)$ & & 94.8 & & 74.0 \\
\hline $\begin{array}{l}\% \text { resp. Qa }(\%) \\
\% \text { resp. }(a-\nabla)_{O_{2}}(\%)\end{array}$ & & $\begin{array}{l}92.9 \\
92.0\end{array}$ & & $\begin{array}{l}60.3 \\
74.9\end{array}$ \\
\hline
\end{tabular}
showing calculation of percentage responses of oxygen consumption and cardiac output

* The heart failure subject is an example of one who showed "normal" blood lactate and arteriovenous oxygen differences at rest and after exercise. Although the patient's $\Delta \dot{Q} a$ is less than that of this particular normal subject, it is about the same as that seen in other normal subjects. 
patient, respectively. Both oxygen consumption values are, however, well within the normal range.

C. In Table $\mathrm{V}$ are given the original data obtained in an additional normal subject and in another patient with heart failure (Class III, 64 years, senile heart disease). Calculating AMR as in A and B gives the values $35.0 \mathrm{ml}$. per minute and $237.5 \mathrm{ml}$. per minute, respectively. Calculating \% resp. $\dot{\mathrm{V}}_{\mathrm{O}_{2}}$ as in $\mathrm{B}$ gives 94.8 per cent and $\mathbf{7 4 . 0}$ per cent for the two subjects. From Line 8 it can be seen that cardiac output increased by $5.77 \mathrm{~L}$. per minute in the normal subject during exercise $(\Delta \dot{Q} a)$, and increased by $3.43 \mathrm{~L}$. per minute in the patient with clinical heart failure. Moreover (Line 9), the final exercise values for arteriovenous oxygen difference $\left(\mathrm{Ca}_{\mathrm{O}_{2}}-\mathrm{C}_{\mathrm{v}_{2}}\right)_{\text {ex. }}$. were $78.9 \mathrm{ml}$. per L. and $105.0 \mathrm{ml}$. per L., respectively. Substituting in Equation 3,

$$
\% \text { resp. } \dot{\mathrm{Q} a}=\frac{\Delta \dot{\mathrm{Q} a}}{\Delta \dot{\mathrm{Q}} \mathrm{a}+\frac{\mathrm{AMR}}{\left(\mathrm{Ca}_{2}-\mathrm{C}_{\mathrm{O}_{2}}\right)_{\mathrm{ex}}}}
$$

the percentage responses of cardiac output are found to be 92.9 per cent for this normal subject and 60.3 per cent for the patient. By a similar substitution from Table $\mathrm{V}$ in Equation 4, the percentage responses of arteriovenous oxygen difference are found to be $\mathbf{9 2 . 0}$ per cent and $\mathbf{7 4 . 9}$ per cent, respectively. The data shown in Table $\mathrm{V}$ for the patient with heart failure give an example of normal cardiac output change with exercise, by our standards, but the percentage responses are quite low. Although the arteriovenous oxygen difference seems somewhat high, some normal subjects exhibit equally high values during exercise.

\section{REFERENCES}

1. Hill, A. V., Long, C. N. H., and Lupton, H. Muscular exercise, lactic acid, and the supply and utilisation of oxygen. Parts IV-VI. Proc. roy. Soc. B $1924-5,97,84$.

2. Jervell, $O$. Investigation of the concentration of lactic acid in blood and urine under physiologic and pathologic conditions. Acta med. scand. 1928, Suppl. 24, 1.

3. Owles, W. H. Alterations in the lactic acid content of the blood as a result of light exercise, and associated changes in the carbon dioxide-combining power of the blood and in the alveolar carbon dioxide pressure. J. Physiol. 1930, 69, 214.

4. Huckabee, W. E. Relationships of pyruvate and lactate during anaerobic metabolism. II. Exercise and formation of $\mathrm{O}_{2}$-debt. J. clin. Invest. 1958, 37, 255.

5. Huckabee, W. E. Relationships of pyruvate and lactate during anaerobic metabolism. III. Effect of breathing low-oxygen gases. J. clin. Invest. 1958, 37, 264.

6. Hill, A. V., and Lupton, H. Muscular exercise, lactic acid and the supply and utilization of oxygen. Quart. J. Med. 1922-3, 16, 135.

7. Harrison, T. R., and Pilcher, C. Studies in congestive heart failure. II. The respiratory exchange during and after exercise. J. clin. Invest. 1930, 8, 291.
8. Katz, L. N., Soskin, S., Schutz, W. J., Ackerman, W., and Plant, J. L. A "metabolic exercise tolerance test" for patients with cardiac disease. Arch. intern. Med. 1934, 53, 710.

9. Herbst, R. Der Gasstoffwechsel als Mass der körperlichen Leistungsfähigkeit. III. Untersuchungen an Herzkranken. Dtsch. Arch. klin. Med. 1928, 162, 257.

10. Huckabee, W. E. Relationships of pyruvate and lactate during anaerobic metabolism. I. Effects of infusion of pyruvate or glucose and of hyperventilation. J. clin. Invest. 1958, 37, 244.

11. Huckabee, W. E. Control of concentration gradients of pyruvate and lactate across cell membranes in blood. J. appl. Physiol. 1956, 9, 163.

12. Huckabee, W. E. Use of 4-aminoantipyrine for determining volume of body water available for solute dilution. J. appl. Physiol. 1956, 9, 157.

13. Huckabee, W. E. Spectrophotometric analysis of uncontaminated blood for oxyhemoglobin. J. Lab. clin. Med. 1955, 46, 486.

14. Hamilton, W. F., Riley, R. L., Attyah, A. M., Cournand, A., Fowell, D. M., Himmelstein, A., Noble, R. P., Remington, J. W., Richards, D. W., Jr., Wheeler, N. C., and Witham, A. C. Comparison of the Fick and dye injection methods of measuring the cardiac output in man. Amer. J. Physiol. 1948, 153, 309.

15. Cotes, J. E. The role of oxygen, carbon dioxide and lactic acid in the ventilatory response to exercise in patients with mitral stenosis. Clin. Sci. 1955, 14, 317.

16. Hallock, P. Lactic acid production during rest and after exercise in subjects with various types of heart disease with special reference to congenital heart disease. J. clin. Invest. 1939, 18, 385.

17. Weiss, S., and Ellis, L. B. Oxygen utilization and lactic acid production in the extremities during rest and exercise. Arch. intern. Med. 1935, 55, 665.

18. Meakins, J., and Long, C. N. H. Oxygen consumption, oxygen debt and lactic acid in circulatory failure. J. clin. Invest. 1927, 4, 273.

19. Furusawa, K., Hill, A. V., Long, C. N. H., and Lupton, H. Muscular exercise, lactic acid, and the supply and utilization of oxygen. VIII. Muscular exercise and oxygen requirement. Proc. roy. Soc. B 1925, 97, 167.

20. Furusawa, K. Muscular exercise, lactic acid, and the supply and utilisation of oxygen. XIII. The gaseous exchanges of restricted muscular exercise in man. Proc. roy. Soc. B 1926, 99, 155.

21. Pappenheimer, J. R. Standardization of definitions and symbols in respiratory physiology. Fed. Proc. $1950,9,602$.

22. Millikan, G. A. Experiments on muscle hemoglobin in vivo; the instantaneous measurement of muscle metabolism. Proc. roy. Soc. B 1937, 123, 218.

23. Peabody, F. W., and Sturgis, C. C. Clinical studies on the respiration. IX. The effect of exercise on 
the metabolism, heart rate, and pulmonary ventilation of normal subjects and patients with heart disease. Arch. intern. Med. 1922, 29, 277.

24. Campbell, J. M. H., and Sale, F. J. Effect of exercise on respiratory exchange in heart disease. II. Arch. intern. Med. 1927, 40, 237.

25. Eppinger, H., Kisch, F., and Schwarz, H. Arbeit und Kreislauf. Klin. Wschr. 1925, 4, 1101.

26. Nylin, G. The practical applicability of the cardiopulmonary function test. Acta med. scand. 1938, Suppl. 93, 1.

27. Sutton, F. C., Britton, J. A., and Carr, J. G. Estimation of cardiopulmonary functional capacity by means of oxygen debt studies. Amer. Heart J. $1940,20,423$.

28. Robinson, S., and Harmon, P. M. The lactic acid mechanism and certain properties of the blood in relation to training. Amer. J. Physiol. 1941, 132, 757.

29. Dill, D. B., Talbott, J. H., and Edwards, H. T. Studies in muscular activity. VI. Response of several individuals to a fixed task. J. Physiol. 1930, 69, 267.

30. Huckabee, W. E. The role of anaerobic metabolism in the performance of mild muscular work. II. The effect of asymptomatic heart disease. J. clin. Invest. 1958, 37, 1593.

31. Mackenzie, J. Diseases of the Heart, 4th ed. London, Oxford Univ. Press, 1925.
32. Starr, I., Jr., and Gamble, C. J. Cardiac output in common clinical conditions, and the diagnosis of myocardial insufficiency by cardiac output methods. Ann. intern. Med. 1935, 91, 569.

33. Stead, E. A., Jr. The role of the cardiac output in the mechanisms of congestive heart failure. Amer. J. Med. 1949, 6, 232.

34. Harrison, T. R. Failure of the Circulation, 2nd ed. Baltimore, Williams and Wilkins, 1939.

35. Judson, W. E., Hollander, W., Hatcher, J. D., and Halperin, M. H. The effects of exercise on cardiovascular and renal function in cardiac patients with and without heart failure. J. clin. Invest. 1955, 34, 1546.

36. Sharpey-Schafer, E. P. Cardiac output in severe anaemia. Clin. Sci. 1944, 5, 125.

37. Bishop, J. M., Donald, K. W., and Wade, O. L. Circulatory dynamics at rest and on exercise in the hyperkinetic states. Clin. Sci. 1955, 14, 329.

38. Fishman, A. P., Maxwell, M. H., Crowder, C. H., and Morales, P. Kidney function in cor pulmonale. Particular consideration of changes in renal hemodynamics and sodium excretion during variation in level of oxygenation. Circulation 1951, 3, 703.

39. Briggs, A. P., Fowell, D. M., Hamilton, W. F., Remington, J. W., Wheeler, N. C., and Winslow, J. A. Renal and circulatory factors in the edema formation of congestive heart failure. J. clin. Invest. 1948, 27, 810. 